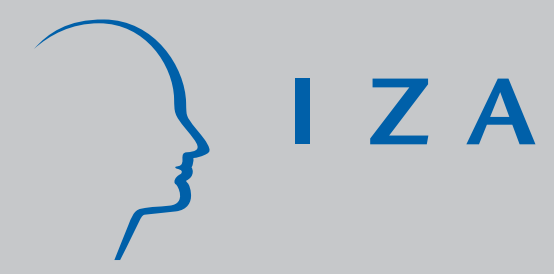

IZA DP No. 3375

Wage Gaps Large and Small

Barry T. Hirsch

February 2008 


\title{
Wage Gaps Large and Small
}

\author{
Barry T. Hirsch \\ Georgia State University \\ and IZA
}

\section{Discussion Paper No. 3375 \\ February 2008}

\author{
IZA \\ P.O. Box 7240 \\ 53072 Bonn \\ Germany \\ Phone: +49-228-3894-0 \\ Fax: +49-228-3894-180 \\ E-mail: iza@iza.org
}

\begin{abstract}
Any opinions expressed here are those of the author(s) and not those of IZA. Research published in this series may include views on policy, but the institute itself takes no institutional policy positions.

The Institute for the Study of Labor (IZA) in Bonn is a local and virtual international research center and a place of communication between science, politics and business. IZA is an independent nonprofit organization supported by Deutsche Post World Net. The center is associated with the University of Bonn and offers a stimulating research environment through its international network, workshops and conferences, data service, project support, research visits and doctoral program. IZA engages in (i) original and internationally competitive research in all fields of labor economics, (ii) development of policy concepts, and (iii) dissemination of research results and concepts to the interested public.
\end{abstract}

IZA Discussion Papers often represent preliminary work and are circulated to encourage discussion. Citation of such a paper should account for its provisional character. A revised version may be available directly from the author. 
IZA Discussion Paper No. 3375

February 2008

\section{ABSTRACT}

\section{Wage Gaps Large and Small}

The law of one wage does not strictly hold, nor should it be expected to hold, in contemporary labor markets. The law of one wage, however, provides a surprisingly good first approximation of the structure of U.S. wages. This generalization is drawn from research on a diverse set of topics: the Mincerian wage equation and earnings imputation, union wage differentials, product market regulation and the labor market, wages in male and female jobs, the wage effects of military service, and interarea wages and cost-of-living.

JEL Classification: J01, J31, J4, J51

Keywords: $\quad$ wage differentials, imputation, unions, cost-of-living, regulation, wages

Corresponding author:

Barry T. Hirsch

Department of Economics

Andrew Young School of Policy Studies

Georgia State University

Atlanta, GA 30302-3992

USA

E-mail: bhirsch@gsu.edu

\footnotetext{
* Presidential Address, presented at the Annual Meeting of the Southern Economic Association (SEA), New Orleans, LA, November 20, 2007. I thank the many economists with whom I have interacted or co-authored over the years, in particular, John Addison, Bill Breit, Bill Johnson, Dave Macpherson, and Ed Schumacher.
} 


\section{Introduction}

In the Wealth of Nations, Adam Smith posited theory and institutional explanations for why wages differ. Modern labor economics has retained a focus on wage differentials. Although much of the literature is unabashedly empirical, it is informed by theory. Neoclassical economics, including human capital theory, remains the principal approach, although labor economists recognize the role played by human nature, workplace incentives, institutions, and public policy in wage determination.

In this address, I highlight several topics I have studied, all involving wage gaps. ${ }^{1}$ These include Census imputation methods, union wage premiums, product market regulation and deregulation, wages in male and female jobs, the wage effects of military service, and interarea wages and cost-of-living. The purpose is not to trumpet my work, although it may appear as such, but to draw broader conclusions about labor economists’ understanding of wage determination.

\section{Equalizing Differentials and the Law of One Wage}

The theory of equalizing differentials states that in competitive labor markets, workers with similar skills working in similarly attractive jobs and locations should receive similar compensation. Long-run wage differentials are explained by differences in skill and job disamenities, with a single “price” (wage) conditional on worker and job attributes. ${ }^{2}$ The law of one wage - equal compensation for equivalent workers and jobs - follows naturally from competitive theory.

Empirical studies attempt to test the law of one price in product markets. I.O. economists focus on a narrow set of homogeneous goods in markets with low-cost information and similar transportation costs; say, purchases of electronics and books at Internet sites. International economists test for purchasing power parity (PPP) for homogeneous goods; say, Big Mac prices across countries (for a recent paper, see Parsley and Wei 2007). Even in these markets, there is considerable deviation from the law of one price.

One does not see an equivalent literature in labor economics. Yes, there is a vast literature on wage gaps, but authors rarely characterize such work as a test of a "law of one wage" because there is little expectation that there should be wage equality, even conditional on controls. Why not? First, as emphasized in the literature on personnel economics, pay schemes that maximize profits often involve wages deviating from spot marginal products, thus creating competitive wage differences across similar workers in similar jobs (Lazear and Oyer 2007). Second, there are rigidities in labor markets owing to

\footnotetext{
${ }^{1}$ A quick point on terminology is in order. I will use the terms wage differential and wage gap interchangeably. At times these terms will refer to raw wage gaps and at other times to gaps with controls for other wage determinants. And while I use the term "wage" throughout the paper, it is sometimes used as shorthand for total compensation. The precise meanings of "wage” and "gap” should be clear in context. Finally, wage gaps are reported in log points, which I refer to as percentage changes. They are percentages, albeit ones with an intermediate wage base between the target and reference groups.

${ }^{2}$ Worker heterogeneity in preferences and skills leads to upward-sloping rather than horizontal supply curves in labor markets. Hence, the magnitude of a wage gap is determined at the margin and influenced by the level of demand as well as supply.
} 
imperfect mobility, say from information and search costs, firm-specific training, personal job attachment, or tied household decisions regarding jobs, location, and housing (Manning 2003; Mortensen 2003).

Third are problems of measurement, leading to apparent variation in wages even when there is none. And fourth, even were data error free, we cannot hope to measure all the multitude of worker and job attributes that influence wages.

How bad is it? It depends on whether you see the glass as half-empty or half-full. The Mincerian human capital earnings equation (Mincer 1974; Chiswick 1974) serves as the workhorse of wage gap studies. ${ }^{3}$ Workers' wages are modeled as a multiplicative function of time investments in human capital, in its most basic form with the natural logarithm of earnings a linear function of years of schooling and a quadratic of potential work experience. With the help of a few heroic assumptions, the schooling coefficient is interpreted as a rate of return to schooling investments and the coefficients on the experience profile reflect a combination of postschool investment intensity, investment length, and the returns to postschool training.

For example, estimating this canonical wage equation using the 2004-2006 Current Population Survey (CPS) earnings files and a combined sample of men and women, I obtain:

$$
\begin{array}{ll}
\ln (\text { Wage })=0.887+0.107 \text { School }+.039 \operatorname{Exp}-.067 \operatorname{Exp}^{2} / 100 \quad \mathrm{R}^{2}=.339 \quad \mathrm{n}=354,132 \\
\mathrm{R}_{\mathrm{s}}=10.7 \% & \text { Rate of return to schooling investment } \\
\mathrm{t}^{*}=29.2 & \text { Years experience at peak of earnings-experience profile } \\
\mathrm{T}^{*}=19.2 & \text { Years of positive postschool investment (assumed to equal t*-10) } \\
\mathrm{K}_{0}=.257 & \text { Initial postschool training investment ratio } \\
\mathrm{R}_{\mathrm{p}}=8.7 \% & \text { Rate of return to postschool investment in human capital }
\end{array}
$$

The coefficient on Schooling, .107, is interpreted as an average rate of return (ignored are important issues such as ability bias and selection.); more accurately, it simply says that on average an additional year of schooling is associated with approximately $10.7 \%$ higher hourly earnings. The coefficients on potential experience Exp and its square Exp ${ }^{2}$ imply a peak of earnings at 29.2 years of experience (age 49), an initial investment ratio of .257 that declines linearly over an investment span of 19.2 years, and a rate of return on postschool training investments of 8.7\% (for calculation details, see Mincer 1974; Freeman and Hirsch 2001).

Although this is a highly simplistic model, I find it remarkable that a specification using information on only two worker attributes, schooling and age, accounts for a third of the total variation in individual worker earnings and allows us to infer very roughly key human capital investment parameters. ${ }^{4}$

\footnotetext{
${ }^{3}$ For recent work combined with a look back, see the papers in Grossbard (2006).

${ }^{4}$ Of course, positive earnings-schooling and earnings-age relationships are consistent with alternative models of the earnings generation process.
} 
I next estimate a dense specification of the Mincerian wage equation of the sort seen widely in the literature. This includes 77 rather than 3 explanatory variables, many of these being dummy variables for such things as schooling degree, broad occupation and industry, region, city size, and a host of demographic variables. There is a labor economics literature surrounding most of these variables. Introduction of 74 additional covariates raises the $\mathrm{R}^{2}$ to “only” .528, or from about a third to a half. Indeed, it is rare that one accounts for over half of the individual variation in earnings in a wage equation.

Is one half high or low? Some argue this is low and suggest that much about earnings determination is inexplicable, say the result of luck or randomness in the labor market. I take the half-full rather than half-empty view, for those same reasons stated earlier as to why we do not test a law of one wage. For example, while we account for schooling, potential experience, and other personal and location attributes, these are imperfect measures of human capital, failing to measure the quality of training, worker ability, and personal motivation, all of which affect productivity and earnings. Mismeasurement of earnings and other attributes is likely to increase the residual variation. For example, I excluded from the estimation samples the roughly $30 \%$ of workers who do not report their earnings and instead have them imputed or assigned by the Census (a topic I return to shortly). Had I included imputed earners, as is standard in the literature, this would lower the $\mathrm{R}^{2}$ by 6 points, from .528 to .466 .

No apology is needed for accounting for only half of measured earnings. That said, measurement and specification issues make it difficult to interpret the residual variance and thus say just how large is the deviation from the law of one wage. ${ }^{5}$ Where the Mincer equation has proven itself invaluable is in the study of key wage determinants. Much of my work, at least what I focus on in this lecture, examines labor market wage gaps that shed light on specific topics, for example, union wage premiums or interarea wage differences. I will argue that such studies also tell us something about the competitiveness of U.S. labor markets and whether the law of one wage provides a reasonable first approximation of how wages are determined.

\section{Match Bias from Imputation: Wage Gaps Larger than We Think?}

A theme running through empirical labor studies is that better control for and measurement of worker and job attributes will lessen the magnitude of what appear to be noncompetitive wage gaps. Estimated wage gaps due to, say, unions, employment in large firms, industry, marriage, etc. would be smaller if only we had better measures of relevant worker skills and job attributes correlated with these regressors. Such reasoning is logical and often correct. For example, Hirsch (2005) shows how part-

\footnotetext{
${ }^{5}$ Likewise, a large residual variance associated with imperfect models and data limits our understanding of wage inequality.
} 
time/full-time wage gaps for women and men decline as one controls for worker, location, and detailed job characteristics. ${ }^{6}$

In this section, I discuss my research on Census earnings imputation and what I have dubbed “match bias” (Hirsch and Schumacher 2004; Bollinger and Hirsch 2006). Routine inclusion of imputed earners in wage regressions not only increases residual wage dispersion, as one would expect, but severely attenuates (biases toward zero) wage gap estimates for attributes that are not imputation match criteria. This bias affects no small portion of the large literature using the CPS to estimate wage gaps. Many labor market wage differentials are not smaller but, rather, larger than we think. Let me explain.

CPS monthly earnings files since 1979 include edited earnings variables in which the Census imputes values for those who refuse or are unable to report earnings, once about $15 \%$ of workers and now about 30\%. Details on the specifics of imputation procedure have not been publicly provided, but were obtained from BLS and Census employees. Labor economists routinely include imputed earners in their samples, either oblivious to the issue or under the belief that the impact is minimal (Angrist and Krueger 1999), as would be expected if measurement error on a dependent variable were random. My work with Ed Schumacher and Chris Bollinger shows that inclusion of imputed earners introduces bias that is systematic and large. Imputed values are obtained by assigning to each worker with missing earnings the earnings of a matched “donor” with an identical set of attributes (gender, plus broad categories for age, race, schooling, occupation, and hours worked). Wage determinants such as union status, industry, foreign-born, Hispanic, marital status, veteran, region, city size, and many others are not imputation match criteria. Inclusion of imputed earners creates "match bias" - attenuation of wage gap estimates with respect to nonmatch attributes. This bias is about $25 \%$ using recent data.

The intuition is straightforward. Consider union status. Union workers who do not report earnings are likely to be assigned the earnings of a nonunion donor. And a small portion of nonunion workers who do not report earnings are assigned the earnings of a union donor. For the $30 \%$ of the estimation sample made up of imputed earners, the union-nonunion wage gap is close to zero. Measures of match bias are derived and alternative estimation approaches are examined in Hirsch and Schumacher (2004) and Hirsch and Bollinger (2006). The simplest approach, and not a bad one at that, is to omit imputed earners from the estimation sample.

In Figure 1, I illustrate the match bias from imputation using results from my 2006 paper with Chris Bollinger. Shown are wage gap estimates associated with the following non-match criteria: union status, foreign born, Hispanic, industry, region, and metro size. The estimates are for men from the 1998-

\footnotetext{
${ }^{6}$ Based on wage level equations, the part-time wage disadvantage among women falls from an unadjusted $22 \%$ to $9 \%$ with a full set of controls. Equivalent estimates among men are $46 \%$ and $19 \%$. Part-time wage gap estimates are even smaller using longitudinal analysis, which identifies the gap based on workers switching between full-time and part-time jobs.
} 
2002 CPS, the proportion of imputed earners being 28.7\% (results for women are included in the article). In each example, the "unbiased" respondent sample estimate is shown in the third bar. Estimates for the full sample and imputed earners are shown in the first two bars. The full sample estimates, standard in the literature, are roughly a weighted average of the other two.

Attenuation from match bias is severe, approximately 25\% in each case. For example, the biased full sample estimate of the union wage gap is .142 log points, 26\% lower than the .191 estimate obtained from the respondent sample (and .024 among the sample of imputed earners). Comparing foreign born to native workers, the full sample estimate is a -.099 earnings disadvantage for foreign-born workers, versus a respondent sample estimate of -..130, attenuation of 24\%. And so forth. Attenuation in industry, city size, and region wage gaps can be seen by comparing the mean absolute deviation across coefficient estimates. The mean absolute deviation across 7 city size categories, for example, is .094 in the full sample versus .125 in the respondent sample (and .011 in the imputed sample), a downward bias of 25\%. These examples show that match bias from earnings imputation is a first-order problem for CPS wage gap estimates for non-match earnings attributes.

Among earnings attributes that are imputation match criteria, but are matched imperfectly, match bias is more complex (Bollinger and Hirsch 2006). For example, earnings nonrespondents are assigned the earnings of a donor based on three broad education categories, those without a high school degree, those with a high school degree (including a GED) or some college, and those with a BA degree or above. As one would expect, for those with imputed earnings, wages do not rise in steady lock-step with education, but in three rather flat steps with large jumps between the education categories. This is readily evident in Figure 2, showing the returns to schooling among women (the same pattern is seen for men). The “diamond” line shows earnings for respondents. The "square” line shows the imputed earnings for nonrespondents. Respondent earnings rise systematically with schooling. Nonrespondents’ imputed earnings are flat within schooling match categories, but jump dramatically between categories.

Bias can be extreme for those with earnings far from the weighted average within an education category, for example those with a PhD or GED (on the latter, see Heckman and LaFontaine 2006). As evident in Figure 2, the returns to a GED are greatly exaggerated due to imperfect donor matching, since most nonrespondents with a GED are assigned the earnings of a donor with a regular high school degree or some college. Just the opposite bias is found for those with a $\mathrm{PhD}$, since those who fail to report earnings are assigned earnings of donors primarily with a BA degree. By contrast, there is little bias found for those with the BA degree, since most BA nonrespondents will be assigned the earnings of a BA donor.

Note that the "match bias" I have discussed is a result of imputation and exists even if nonresponse is random. Corrections for match bias, however, including the use of the respondent-only 
sample, assume that nonresponse is conditional missing at random, with no difference in earnings among respondents and nonrespondents once one conditions on measured earnings attributes. In on-going work with Chris Bollinger (Bollinger and Hirsch 2007), we use selection models and longitudinal analysis to evaluate whether there exists response bias and to examine the relationship between proxy household respondents and nonresponse. Our preliminary conclusion is that there is negative selection into response, but it is restricted to men in the tails of the distribution. Proxy earnings responses exhibit small differences from self-reported earnings. Whatever the precise magnitude of response bias, it is of secondorder importance as compared to match bias.

\section{Union Wage Gaps}

H. Gregg Lewis is widely associated with the notion that union wage premiums are on the order of $15 \%$, although a careful reading of his work reveals that he thought the true figure was lower (Lewis 1986). A principal argument for a premium lower than standard OLS estimates is that high union wages should be competed away, at least in part, through skill upgrading. A second stylized "fact" about union wages is that premiums are highest for low-skill workers and lowest for high-skill workers.

My work has questioned these two stylized facts, both the importance of skill upgrading and the large differences in premiums across worker groups. Skepticism on skill upgrading is warranted on several grounds. First, in most union work settings, both management and union rank-and-file clearly believe the union wage impact is $15 \%$ or higher, a belief viewed negatively by management and positively by unions. Second, a related literature on the productivity of union and nonunion companies does not offer evidence supporting skill upgrading. While these studies leave much to be desired, U.S. evidence suggests an average union productivity effect that is positive, but small and possibly zero, and highly variable across firms and industries (Hirsch 2004). Third, and most important, skill upgrading need not follow in theory in a repeated bargaining framework. As argued by Wessels (1994), if firms upgrade in response to a union wage increase, the union can bargain in a future period to restore the premium. Employers, anticipating this, may choose not to upgrade. In short, it does not necessarily follow that firms can or will use skill-upgrading to offset union wage increases.

My work on union wage premiums concludes: 1) the union wage premium exceeds the Lewis consensus, with premium estimates higher than typically seen in the literature and declining less over time; and 2) union premiums differ relatively little with respect to measured skill level. The first conclusion is a clear-cut result of accounting for imputed earnings and is (now) uncontroversial for those familiar with this problem. The second conclusion rests on limited longitudinal evidence that is rather less clear-cut.

We saw previously that inclusion of imputed earners causes union premium estimates to be attenuated by about 25\%. The impact was less for earlier years when imputation rates were lower. 
Census did not impute earnings among non-respondents in the earnings files prior to 1979, so 1973-78 estimates are not affected by imputation. In Figure 3, CPS estimates of the union-nonunion wage premium in the private sector are shown, these from my 2004 paper with Ed Schumacher which first addressed the match bias issue.

Estimates in the literature use the 1973-78 CPS, shown by the first six squares, and then beginning in 1979, the Census began inclusion of imputed earners in the public use CPS files, these full-sample estimates shown by the diamonds. Based on the full-sample series, one observes a puzzlingly large drop in the union premium between 1978 and 1979 (moving from the 1978 square to 1979+ diamond series) and a relatively gradual but large decline in the union premium since the early 1980s. Each of these patterns is due in no small part to the effect of imputed earners.

About two-thirds of the apparent decline in the premium between 1979 and 1980 was due to the introduction of earnings imputations in the Census public use files, an event unannounced to researchers. This puzzling result was discussed in a 1986 book by Lewis and 1986 article by Richard Freeman, but not resolved. Second, one sees that union wage premium estimates are considerably higher once one omits or otherwise corrects for the match bias due to imputed earnings. The bias due to imputation is the principal reason why my belief about the magnitude of the union premium exceeds the conventional wisdom. And third, while there is decline in the union wage premium since 1983, it is far less than one would conclude based on use of the full CPS samples containing increasing numbers of imputed earners. Private sector union density has declined from $24.2 \%$ to $7.4 \%$ since 1973 , but union wage effects have remained substantial. I should note that since 2001, there has been little change in the union wage premium (Hirsch and Macpherson 2007). ${ }^{7}$

The other stylized fact I have questioned regarding union premiums is that that they are substantially higher for low-skill than for high-skill workers. This result shows up in standard crosssectional regression analysis. For example, in Figure 4, I present wage level estimates from the 1989-94 CPS (Hirsch and Schumacher 1998). The overall union premium is estimated as $18 \%$, but this ranges from $24 \%$ for dropouts, $20 \%$ for high school grads, $17 \%$ for those with some college, and only $8 \%$ for those with a BA or above. The CPS sample also permits panel estimation, with individual workers interviewed in consecutive years. Wage change equation based on the 1989-90 through 1993-94 matched samples identify the union wage effect based on workers switching union status, from union to nonunion

\footnotetext{
${ }^{7}$ I ignore several estimation issues. Eren (2007) provides non-parametric matching estimates of the union premium using the PSID. He shows that conditioning linearly on wage covariates (as in OLS) causes a downward bias in the union gap. Eren also finds that log wage estimation biases upward the percentage union gap, as shown previously in Blackburn (2007).
} 
or nonunion to union, thus controlling for unmeasured worker heterogeneity (fixed effects). The longitudinal estimates are virtually identical across the four schooling groups $-12 \%{ }^{8}$

The sharp difference between the wage level and the longitudinal estimates is due to two-sided selection (Card 1996). Among workers with low credentials (say, dropouts) there is positive selection, union employers are likely to hire and retain only those with high unmeasured skills. Among those with high credentials (college grads), workers most likely to be in the union job queue are those with low unmeasured skills compared to the average college graduate. The fact that unions compress wages, both across and within positions, accentuates the two-sided selection, leading to a high degree of homogeneity within union workplaces.

The evidence on union wage premiums indicates that they are large and are not accounted for by unmeasured skills or by higher productivity in union workplaces, at least not to any major degree. Union premiums provide a clear violation of the law of one wage. As unions have attempted to maintain their wage advantage, competitive forces, combined with managerial antipathy, have sharply eroded density, unions now surviving in increasingly tiny pockets of the private sector economy (Hirsch 2008).

\section{Regulation, Product Market Competition, and Unions}

Labor demand is derived from product demand. Thus, a regulated product market in which price competition and entry are restricted may produce rents that can be captured in part by unions. I have examined the labor market effects of deregulation in trucking and airlines. ${ }^{9}$ The theoretical and empirical framework used to analyze these industries is similar. But outcomes in these industries have proven rather different.

Trucking provides a nearly textbook example of the role of competition. As seen in Figure 5, in 1976, prior to deregulation, $42 \%$ of truck drivers were union members ( $60 \%$ in the regulated for-hire sector); density among all workers across the regulated for-hire trucking industry was $48 \%$. Just ten years later, following deregulation, density had declined to $28 \%$ among all truck drivers and to $27 \%$ among all employees in the for-hire industry. By 2006, density is $15 \%$ and $12 \%$, respectively, a fraction of what it was prior to deregulation, although higher than the $7.4 \%$ density for the entire private sector.

Union drivers realized substantial wage premiums during the regulatory period (Rose 1987; Hirsch 1988). Some rents spilled over to nonunion drivers and non-regulated sectors of the industry. Deregulation brought about rapid entry of nonunion trucking operations and a shift of traffic from company-operated trucks toward the increasingly competitive for-hire sector. Real wages for drivers fell.

\footnotetext{
8 These results are affected by incomplete removal of imputed earnings and incomplete correction for measurement error in union status. The latter biases downward the longitudinal estimates, although we have little reason to believe differences across schooling groups are greatly affected. For a related analysis, see Card (1986).

${ }^{9}$ See Hirsch $(1988,1993,2007)$ and Hirsch and Macpherson (1998, 2000). In related fashion, unions have captured and largely maintained gains for their members in the regulated U.S. Postal Service (Hirsch, Wachter, and Gillula 1999).
} 
Union drivers continued to receive higher wages than nonunion drivers, although much of the remaining union wage advantage reflects occupational experience and driver-specific skills (Hirsch 1993). In short, easy entry and competition largely eliminated systematic rents from what is a naturally competitive industry. Standard theory does a good job accounting for the outcome of trucking deregulation.

Of course de-unionization has not been restricted to previously regulated industries. Even in automotive vehicles and parts, those quintessential union industries, competitive forces eventually produced a marketplace in which prices and wages were increasingly determined by nonunion rather than unionized companies (Hirsch 2008). Figure 6 shows that total employment in the vehicle and parts industries has increased between 1973 and 2006, but have transitioned from largely union to largely nonunion industries.

Results in the airline industry look rather different from trucking or automotives. Roughly half of all workers in the air transportation industry were union members prior to deregulation; approximately half are union members today. With the exception of Delta, nearly all flight and ground workers among the major carriers are unionized. Union employment and wages in the airline industry are far from immune from competitive pressures, however. Apart from American Airlines, every legacy carrier at the time of deregulation has either failed, had its operations merged into another airline, or been in bankruptcy.

Airline unions retain enormous bargaining power; a strike by any major craft has the ability to shut down an entire airline. Such a catastrophic event will be avoided of course. What has emerged is a lagged wage-profit cycle such that airline unions obtain substantial wage premiums following good times and agree to concessions following bad times. In Figure 7, estimates are shown for the period 1995 to 2006, which includes both good and bad times. Union pilots, flight attendants, mechanics, fleet service, and agents received an average estimated wage premium of 25\%, as compared to non-airline employees at similar levels of work (Hirsch 2007). Premiums are particularly large for union pilots at 36\%, while running from $17 \%-22 \%$ for other crafts. There is little wage advantage, on average, for nonunion workers.

In the late 1990s, airlines realized strong profits. Contracts negotiated as this period was ending promised large future pay increases. A “perfect storm” of events then occurred in the early 2000’s as these pay increases took effect - a recession, reduced traffic following the 9/11 attacks, Internet pricing that lowered carriers' margins, destruction of pension wealth in the 2000 market decline, and, later, rising fuel costs. Something had to give. US Airways, United, Delta, and Northwest went into bankruptcy in order to reduce their debt and force substantial labor concessions. American narrowly avoided filing for bankruptcy in 2003 following union concessions. Labor relations at several (but not all) carriers went from historically bad to worse as labor concessions took place. 
The decline in labor costs coupled with robust demand allowed major U.S. carriers to return to profitability in 2006, despite high fuel costs. As these labor agreements expire in the coming years, the real test for the industry begins. The lessons learned during the "perfect storm” no doubt differ for airline workers and management. Union rank-and-file want to regain wages and benefits lost under the threat of bankruptcy. Yet if they press too hard to do so, we will see a continuation of the profit-wage cycling that has proven unsustainable in the past.

Management will resist pay demands unlikely to permit long-term profitability, but in a crunch they have little choice. It is conceivable, although perhaps not likely, that there will be agreements that provide modest wage increases maintaining cost-competitive compensation. Carriers achieving this outcome might prosper and provide job security to their workforce. Airline workers would continue to receive compensation superior to that available outside the industry.

What I do not see in the airline industry in the near future is widespread de-unionization or a shift to competitive, opportunity cost wages; that is, what we saw in the deregulated trucking industry, or what is currently occurring in the automotive assembly and parts industries. Yes, product market competition limits prices and what unions can demand, but does not prevent the sharing of rents and quasi-rents. It is possible, perhaps likely, that a competitive pay level will eventually emerge in the airline industry. But nearly 30 years after deregulation, that outcome is not imminent.

\section{A Tale of Two Jobs: Nursing, Truck Drivers, and Comparable Worth}

This section draws on three seemingly unrelated lines of research that, taken together, illustrate important features of the U.S. labor market. First is the work discussed above on deregulation and truck driver earnings. Second is research with Ed Schumacher examining the earnings of registered nurses (RNs). A principal focus of that research is the role of "classic" and "new" monopsony on the earnings of hospital RNs (Hirsch and Schumacher 2005). We find that RNs display substantial mobility across employers and that hospital concentration has little effect on RN wages. Third is work with Dave Macpherson (1995) in which we examine the role of occupational segregation by sex on the earnings of women and men. Although earnings are higher in predominantly male and lower in predominantly female occupations, we conclude that much (not all) of the effect of gender composition is accounted for by worker heterogeneity, job skill requirements, and working conditions. Gender composition explains only a modest amount of the overall gender wage gap.

These disparate lines of research are used below to illustrate two of the more important features of the U.S. labor market since the mid-1970s, widening wage differentials with respect to skill and a narrowing of the gender wage gap. The evidence also suggests that the sex composition of occupations is not a primary wage determinant. 
During the 1970s and early 1980s, there was considerable interest in “comparable worth” legislation (e.g., Killingsworth 1990). The intent was to narrow the gender wage gap by administering wages based on job evaluations that measure the skills, responsibilities, and working conditions of jobs. Underlying the argument for comparable worth was the belief that “female jobs” are systematically undervalued in the labor market. A common example used at the time was that male truck drivers were being paid more than were female registered nurses, despite that fact that the latter occupation requires considerably more skill.

I will not revisit arguments for and against comparable worth, but it is worth examining wage changes among truck drivers and registered nurses since that time, as shown in Figure 8. First, the stylized "fact" that male truck drivers were paid more than female RNs in the 1970s was never a fact, the average wage (in 2006\$) for male drivers in 1976 being $\$ 18.18$ and for female RNs $\$ 19.98$. It is true that union truck drivers, with an average wage of \$22.82, earned more than RNs, but even at that time, 58\% of drivers were not union members.

Since the mid-1970s, it is difficult to identify major occupations with slower wage growth than truck drivers or major occupations with faster wage growth than nursing. By 2006, the mean wage of female RNs is $\$ 27.85$, far higher than the \$15.64 found for male truck drivers. In 2006, only $14.7 \%$ of truck drivers were unionized, and their earnings (\$20.94) are substantially below that of the average nurse. The near absence of comparable worth legislation does not appear to have retarded wage growth among nurses or to have bolstered it among truck drivers. ${ }^{10}$

If gender composition does not explain the large change in relative wages among truck drivers and nurses, what does? Some of the decline in trucking wages from their 1970s level was the result of deregulation and the erasure of labor rents brought about through entry, price competition, and deunionization. The longer run trends, however, say more about changing skill premiums in the US economy. Relative labor demand and wages for male semi-skilled and low-skilled workers declined throughout the economy. While employment for production workers in manufacturing stagnated due to labor-saving technology, demand for truck drivers has remained robust. But entry into trucking is relatively easy, the principal barriers being clean driving records, drug testing, and, for long-haul drivers, time away from home. Absent entry barriers, trucking wages have declined along with those for other low- and semi-skilled workers.

RN wage growth during these years has exceeded the average for all college-educated women, which in turn has exceeded growth economy-wide. Such rapid growth appears to be best explained by

\footnotetext{
${ }^{10}$ Gender segregation in these occupations has moderated, but not dramatically so. The proportion of truck drivers who are men decreased from 97 to 95 percent between 1983 and 2006. During the same period, the proportion of RNs who are women fell from 96 to 92 percent (Hirsch and Macpherson, 1994, Table 8c; 2007, Table 8a).
} 
slow labor supply relative to demand growth. As sex discrimination declined and employment opportunities for college-educated women improved, labor supply in traditional female jobs such as nursing and teaching has fallen. Despite rising demand for health care workers, the supply of RNs has been restricted by limits on the number of enrollment slots made available in nursing training programs.

My research on sex segregation and the gender wage gap, nursing monopsony, and unions and trucking regulation, were unrelated projects addressing different questions. Yet, taken together, they provide a revealing tale of two occupations. The disparate wage paths seen for nurses and truck drivers nicely illustrate important features of the contemporary labor market - a rising skill premium, the declining gender wage gap, and, a rather modest causal impact of gender composition on wages.

\section{Military Service and Civilian Earnings}

Another line of research in which I have estimated wage gaps, early in my career with Mark Berger (Berger and Hirsch 1983) and twenty years later with Steve Mehay (Hirsch and Mehay 2003), is the effect of military service on subsequent civilian earnings. The work with Mark focused on Vietnamera veterans, although we examined earlier cohorts of veterans as well. The results of that research, which suggested small negative effects of Vietnam-era military service, hold up surprisingly well. ${ }^{11}$ But a severe limitation of our work was the inability to account explicitly for double-sided selection, a selection mechanism among recruits to enter the military queue and selection from the queue by the military.

The earnings effect of Vietnam-era service (1964-1975), when the draft played a major role, cannot be generalized to the post-1973 period of the all-volunteer military. But theory is helpful, specifically the law of one wage. Given reasonable assumptions, we expect that for the marginal (voluntary) military entrant, expected gains from time spent in active-duty military service should roughly equal equivalent time spent working in the civilian labor market. This is what standard OLS wage analysis from the CPS indicates, but CPS data provide no obvious way to account for selection.

My work with Mehay arguably accounts for selection during the all-volunteer era, not through use of using instrumental variables but through reliance on a unique database. We examine a survey of military reservists that includes both standard CPS type variables (including current civilian earnings) and detailed information on past military service. The reservist sample is an interesting one. First, it contains a mix (about 60-40) of veterans (i.e., those with active-duty service) and nonveterans. Second, the reservist sample of nonveterans arguably provides a matched comparison group for veterans that accounts for selection. The criteria for service in the reserves are nearly identical to those for active-duty service, thus accounting for selection by the military. And one can argue that many of the preferences that would lead individuals to choose military service would be similar for active-duty and reserve service. If one

\footnotetext{
${ }^{11}$ Angrist and Chen (2007), who revisit earlier work on those affected by the Vietnan-era draft lottery, conclude that the longrun effects of military service on civilian earnings were minimal.
} 
buys into our argument, then comparison of civilian earnings among reservists with and without activeduty service provides reliable estimate of the civilian wage effect of military service. ${ }^{12}$

What do we find? The results are close to what is found using standard OLS analysis from the CPS. ${ }^{13}$ There is a close-to-zero wage difference associated with active-duty military service, a zero average treatment effect among the treated. More precisely, among the enlisted ranks, there is a small negative veteran effect of a percent or two, with some differences seen by military branch and variation in results depending on whether one’s military occupation matched one’s broad civilian occupation.

Although the principal story is that active-duty service has a close to zero average treatment effect, other intriguing results emerge. We find that it is essential to separate officers from enlisted personnel, something not possible with most data sets. ${ }^{14}$ An additional finding concerns race. Previous studies, including my earlier work with Berger, find positive military service wage gain for blacks but not whites. I had been skeptical of this result, believing that much of the difference was likely to reflect selection; that is, unobserved differences between black veterans and nonveterans. I was surprised to see a substantial veteran-nonveteran wage advantage among black reservists, convincing me that for the larger population of African Americans, the wage advantage among veterans is to some degree a causal effect of military service.

Finally, the reservist sample contained a reasonably large sample of women, a group that only recently could be studied (Mehay and Hirsch 1996). Using standard CPS data, we find little wage difference between female veterans and nonveterans, seemingly consistent with evidence for men. But using the reservist sample, which mitigates bias from selection, a civilian wage penalty is found for women with active-duty service. Our interpretation is that during the time period under study, the few women admitted into active-duty service were unusually able (positive selection), but once serving in the military these women were denied access to many of the positions that would provide a subsequent payoff in the civilian sector.

The relevance of research on veterans for this address is twofold. First, evidence that active-duty military service and civilian experience among men have similar effects on subsequent earnings provides yet another example where the competitive model and law of one wage provide a good first approximation as to how labor markets work. Second, it further illustrates how theoretical guidance, knowledge of institutions, and appropriate data are essential for interpreting evidence and drawing reliable conclusions.

\footnotetext{
${ }^{12}$ In the paper we discuss reasons whether or not the active-duty "treatment" effect for reservists might be safely generalized to the larger population including non-reservists.

${ }^{13}$ The similarity suggests that using OLS estimates from the CPS, positive selection bias at the low end of the quality distribution is roughly cancelled out by negative selection bias at the upper end.

${ }^{14}$ Whereas enlisted personnel displayed a close-to-zero veteran-nonveteran wage gap, there is a substantial veteran wage advantage for officers. We discuss reasons for this gap in the paper.
} 


\section{Area Wage Differentials}

There is little mystery as to why large wage differences across countries are sustained, given language, immigration, and other mobility impediments. Less easy to understand are wage differences across U.S. labor markets, even after accounting for education, age, and other worker and job attributes. What's going on? This is not the place to provide a comprehensive answer. But I will address a popular response to that question - the assertion that wage differences largely reflect cost-of-living differences. Anecdotal evidence of such a response can be seen by the existence of Internet sites providing city costof-living calculators intended to compare so-called real wages.

Labor and urban economists examining interarea differentials typically focus on nominal wages. In part, a reluctance to adjust for cost-of-living stems from concerns about price data availability and quality. But caution is also warranted because of theoretical ambiguity. Yes, all else the same, workers require higher wages to work in high cost-of-living areas. But area amenities and disamenities are not easily measured. Amenities valued by workers (say, good weather, being near water, low crime, good schools) tend to lower wages, all else the same, while driving up land values and measured cost-of-living (Roback 1982). The law of one wage leads not to the conclusion that either nominal or cost-of-living adjusted (so-called “real”) wages should be equal across markets but, rather, the utility of equivalent workers should equalize at the margin. High prices not driven by area amenities require higher compensation, but high prices reflecting amenities have an ambiguous effect on wages. Wages rise with cost-of-living, but not one-for-one. ${ }^{15}$

What is the evidence? In a paper with Mike DuMond and Dave Macpherson (DuMond et al. 1999), we use individual worker data for 1985-1995 to examine wage differences across 185 U.S. metropolitan areas. One question we ask is whether adjusting wages fully for cost-of-living leads one to see lower wage dispersion across cities. The answer is no. Shown in on the left side of Figure 9 is the mean absolute wage dispersion across metropolitan areas, after controlling for numerous worker, job, and location characteristics. We measure intercity dispersion using four approaches, one using nominal wages, a second with wages fully adjusted for cost of living, and a third and fourth in which we control for the log of the area price index on the right-hand-side of the wage equation, thus allowing partial adjustment for cost of living, in one case with a linear term and the other with a quadratic.

Results are clear-cut. In the wage equations without area amenities, the mean absolute deviation of unexplained intercity nominal wage dispersion is .07 log points. Adjusting fully for cost of living (so-

\footnotetext{
${ }^{15}$ It is more complicated than this. As argued above, utility maximization among workers does not lead to equal wages, nominal or price-adjusted. Firms, however, seek to maximize profits. If output is sold largely outside of the local (i.e., producing) marketplace, firms should locate where nominal labor (and other operating) costs are lowest. Firm location decisions, therefore, would tend to equalize nominal wages. If large cities with high prices and wages are to maintain these differentials, then there must be offsetting productivity advantages attached to city size (see, for example, Rauch 1993).
} 
called real wages) increases dispersion to .08. However, partial adjustment for price differences sharply reduces intercity wage differences, to .04 based on a linear and .035 based on a quadratic adjustment.

As evident on the right-side of Figure 9, explicitly accounting for measurable area amenities reduces unexplained wage differentials across markets. Dispersion is larger using "real” rather than nominal wages, but lower with partial adjustment for cost of living. In short, much of what appear to be unexplained wage differences across labor markets can be accounted for by controlling for area amenities and providing partial adjustment for cost of living, with wages rising about half as fast as do prices.

This same pattern can be seen looking at regional and city size differentials. For example, over the years there has been a literature examining wage differences between the south and non-south, most recently an Association Lecture given at last year's SEA Meetings in Charleston by Ed Glaeser (Glaeser and Tobio 2008). Conclusions regarding relative wages in the south are highly sensitive to treatment of cost of living, as evident in Figure 10. In DuMond et al. (1999), nominal wages in southern cities are almost .08 lower than in the non-south, absent control for city size or amenities. Controlling fully for cost-of-living, the $8 \%$ wage disadvantage flips to an $8 \%$ advantage. Neither so large a wage advantage nor disadvantage is plausible by the 1990s. With partial adjustment, effected by inclusion of $\ln P$ in the wage equation, we obtain a southern wage disadvantage close to zero. Adding control for city size (as in the middle set of bars) or amenities (on the right side) compresses these differentials further. With partial price adjustment there is no southern wage penalty - or premium - requiring explanation.

The story with city size (not shown) is much the same. Workers in the largest metropolitan area realize large nominal wage advantages; with full price adjustment the estimate flips to a wage disadvantage, and with partial adjustment for prices a plausible (i.e., small) wage gap estimate in between the other two is obtained.

What is the implication of this analysis? The obvious implication is that interarea wage differences are far smaller than commonly believed. They are not zero, but we are much closer to the law of one wage than standard analysis would lead us to believe. The appropriate area wage "calculator" is not one that adjusts by an area price index, but rather by a wage index that compares workers of similar skill in similar occupations across cities.

\section{Summing Up}

This address pulls together several strands of my research. The studies discussed differ in subject matter, groups studied, and questions being asked. They have in common a focus on wage determination and wage gaps. The theoretical approach across many of the studies is similar, as are empirical methods and some of the data sources. Can these disparate lines of research be used to make general statements about wage gaps or to draw lessons about the study of wage determination? At a broad level, I contend that the answer is yes. Our understanding of the economic theory of labor demand, labor supply, and 
human capital provides a common foundation or framework for interpreting empirical evidence. There are numerous reasons why Adam Smith's theory of compensating wage differentials and the law of one wage should not and does not strictly hold in real-world labor markets. Yet the law of one wage provides a fundamental and remarkably useful approach not only to describe market wage determination, but also to identify and interpret existing wage gaps. It remains our single most powerful tool and the necessary starting point for most wage analyses. This is no small thing.

But I see the lessons learned as more idiosyncratic. The theory of compensating differentials and law of one wage is just a starting point, providing only a rough approximation of real world markets. Yes, the basic theory is powerful. And no doubt it is important that we proselytize the virtues (and limitations) of standard theory to students and non-economists. For me and perhaps most labor economists, however, it is more enlightening and rewarding to focus instead on the heterogeneity of labor market outcomes. It is in understanding heterogeneity that theoretical and empirical labor economics tends to advance. Deep insight and an understanding of how labor markets operate require a nuanced perspective, one that extends beyond a textbook description of markets and includes knowledge of institutions, law, and history. Psychology and sociology likewise can inform our understanding of labor markets, although these approaches are less evident in my work.

A more mundane but no less important lesson learned is that data issues are important. One cannot reliably know what data tell us if one does not first understand data limitations and strengths. Such an understanding requires thorough knowledge of how data surveys are constructed and attention to a host of measurement and estimation issues. Empirical work also requires meticulous attention be given to programming and documentation, to make sure data are more rather than less reliable once they have been processed and manipulated by the researcher.

I have found that empirical explorations examining particular labor markets, say, nursing or airlines, or those addressing policy or other questions of interest about labor markets, for example, the effects of deregulation on unions and earnings, to be worthy and fulfilling endeavors. Apart from their specific contributions, they have provided me, and perhaps a few readers, with a better understanding of the diversity of economic and social arrangements that have evolved across U.S. labor markets. 


\section{References}

Angrist, Joshua D. and Stacey H. Chen. 2007. Long-term consequences of Vietnam-era conscription: Schooling, experience, and earnings. NBER Working Paper 13411, September.

Angrist, Joshua D. and Alan B. Krueger. 1999. Empirical strategies in labor economics. In Handbook of Labor Economics, Vol. 3A, edited by Orley C. Ashenfelter and David Card. Amsterdam: Elsevier, pp. 1277-1366.

Berger, Mark C. and Barry T. Hirsch. 1983. The civilian earnings experience of Vietnam-era veterans. Journal of Human Resources. 18:455-79.

Blackburn, McKinley L. 2007. Estimating wage differentials without logarithms. Labour Economics 14:73-98.

Bollinger, Christopher R. and Barry T. Hirsch. 2006. Match bias from earnings imputation in the Current Population Survey: The case of imperfect matching. Journal of Labor Economics 24:483-519.

Bollinger, Christopher R. and Barry T. Hirsch. 2007. How well are earnings measured in the Current Population Survey? Bias from nonresponse and proxy respondents. Unpublished paper.

Card, David. 1996. The effect of unions on the structure of wages: A longitudinal analysis. Econometrica 64:957-79.

Chiswick, Barry R. 1974. Income inequality: Regional analyses within a human capital framework. New York: Columbia University Press and NBER.

DuMond, J. Michael, Barry T. Hirsch, and David A. Macpherson. 1999. Wage differentials across labor markets and workers: Does cost of living matter? Economic Inquiry 37:577-98.

Eren, Ozkan. 2007. Measuring the union-nonunion wage gap using propensity score matching. Industrial Relations 46:766-80.

Freeman, James A. and Barry T. Hirsch. 2001. Do returns to human capital equalize across occupational paths? Research in Labor Economics 20:217-42.

Freeman, Richard B. 1986. In search of union wage concessions in standard data sets. Industrial Relations 25:131-45.

Glaeser, Edward L. and Kristina Tobio. 2008. The rise of the sunbelt. Southern Economic Journal 74:610-43.

Grossbard, Shoshana. 2006. Editor, Jacob Mincer: A pioneer of modern labor economics. New York: Springer.

Heckman, James J. and Paul A. LaFontaine. 2006. Bias-corrected estimates of GED returns. Journal of Labor Economics 24:661-700.

Hirsch, Barry T. 1988. Trucking regulation, unionization, and labor earnings: 1973-1985. Journal of Human Resources 23:296-319.

Hirsch, Barry T. 1993. Trucking deregulation, unionization, and earnings: Is the union premium a compensating differential? Journal of Labor Economics 11:279-301.

Hirsch, Barry T. 2004. What do unions do for economic performance? Journal of Labor Research Vol. 25:415-55.

Hirsch, Barry T. 2005. Why do part-time workers earn less? The role of worker and job skills. Industrial and Labor Relations Review 58:525-51.

Hirsch, Barry T. 2007. Wage determination in the U.S. airline industry: Union power under product market constraints. In Advances in airline economics, volume 2: The economics of airline institutions, operations and marketing, edited by Darin Lee. Amsterdam: Elsevier, pp. 27-59.

Hirsch, Barry T. 2008. Sluggish institutions in a dynamic world: Can unions and industrial competition coexist? Journal of Economic Perspectives 22:153-76.

Hirsch, Barry T. and David A. Macpherson. 1994. Union membership and earnings data book: Compilations from the Current Population Survey (1994 edition). Washington: The Bureau of National Affairs.

Hirsch, Barry T. and David A. Macpherson. 1998. Earnings and employment in trucking: Deregulating a naturally competitive industry. In Regulatory reform and labor markets, edited by James Peoples. Norwell, MA: Kluwer Academic Publishing, pp. 61-112.

Hirsch, Barry T. and David A. Macpherson. 2000. Earnings, rents, and competition in the airline labor market. Journal of Labor Economics 18:125-55. 
Hirsch, Barry T. and David A. Macpherson. 2003. Union membership and coverage database from the Current Population Survey: Note. Industrial and Labor Relations Review 56:349-54, database at www.unionstats.com.

Hirsch, Barry T. and David A. Macpherson. 2007. Union membership and earnings data book: Compilations from the Current Population Survey (2007 edition). Washington: The Bureau of National Affairs.

Hirsch, Barry T. and Stephen L. Mehay, 2003. Evaluating the labor market performance of veterans using a matched comparison group design. Journal of Human Resources 38:673-700.

Hirsch, Barry T. and Edward J. Schumacher. 1998. Unions, wages, and skills. Journal of Human Resources 33:201-19.

Hirsch, Barry T. and Edward J. Schumacher. 2004. Match bias in wage gap estimates due to earnings imputation. Journal of Labor Economics 22:689-722.

Hirsch, Barry T. and Edward J. Schumacher. 2005 Classic or new monopsony? Searching for evidence in nursing labor markets. Journal of Health Economics 24:969-89.

Hirsch, Barry T., Michael L. Wachter, and James W. Gillula. 1999. Postal service compensation and the comparability standard. Research in Labor Economics 18:243-79.

Killingsworth, Mark R. 1990. The economics of comparable worth. Kalamazoo, MI: Upjohn Institute for Employment Research.

Lazear, Edward P. and Paul Oyer. 2007. Personnel economics. NBER working paper 13480, October.

Lewis, H. Gregg. 1986. Union relative wage effects: A survey. Chicago: University of Chicago Press.

Macpherson, David A. and Barry T. Hirsch. 1995. Wages and gender composition: Why do women's jobs pay less? Journal of Labor Economics 13:426-71.

Manning, Alan. 2003. Monopsony in motion: Imperfect competition in labor markets. Princeton, NH: Princeton University Press.

Mehay, Stephen L. and Barry T. Hirsch. 1996. The post-military earnings of female veterans. Industrial Relations 35:197217.

Mincer, Jacob. 1974. Schooling, experience, and earnings. New York: Columbia University Press and NBER.

Mortensen Dale T. 2003. Wage dispersion: Why are similar workers paid differently? Cambridge, MA: MIT Press.

Parsley, David C. and Shang-Jin Wei. 2007. A prism into the PPP puzzles: The micro-foundations of Big Mac real exchange rates. Economic Journal 117:1336-56.

Rauch, James E. 1993. Productivity gains from geographic concentration of human capital: Evidence from the cities. Journal of Urban Economics 34:380-400.

Rose, Nancy. 1987. Labor rent-sharing and regulation: Evidence from the trucking industry. Journal of Political Economy 95:1146-78.

Roback, Jennifer. 1982. Wages, rents, and the quality of life. Journal of Political Economy 90:1257-78.

Wessels, Walter. 1994. Do unionized firms hire better workers? Economic Inquiry 32:616-29. 
Fig. 1: Wage Gap Estimates from Male Full Sample, Imputed Earners, and Respondents

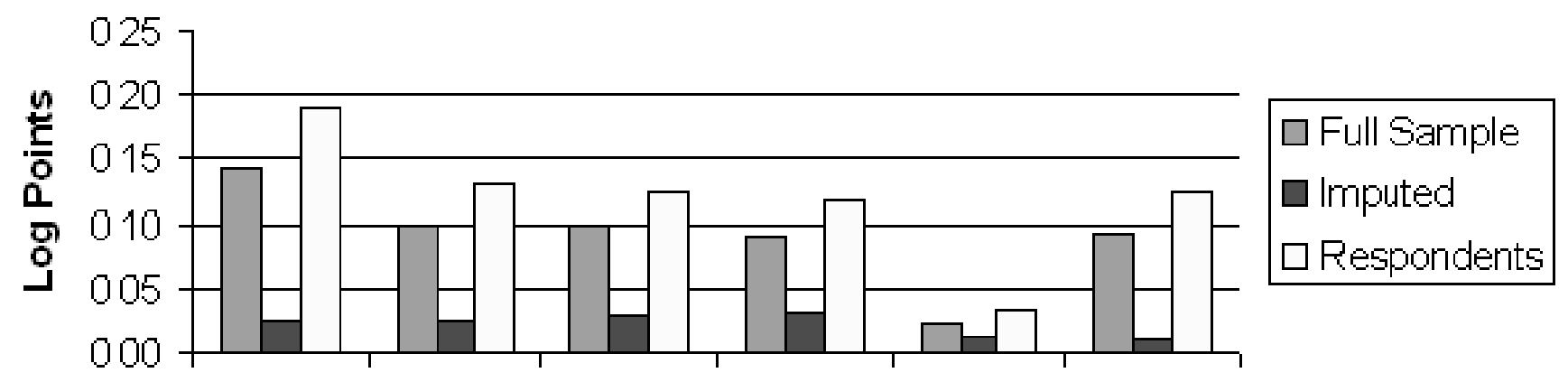

Union Foreign Hispanic Industry Region City Size

Born

Log Wage Gap Mean Absolute Deviation

Source: Bollinger and Hirsch (2006).

Fig. 2: Schooling Returns among Female Respondents and Imputed Earners, 1998-2002

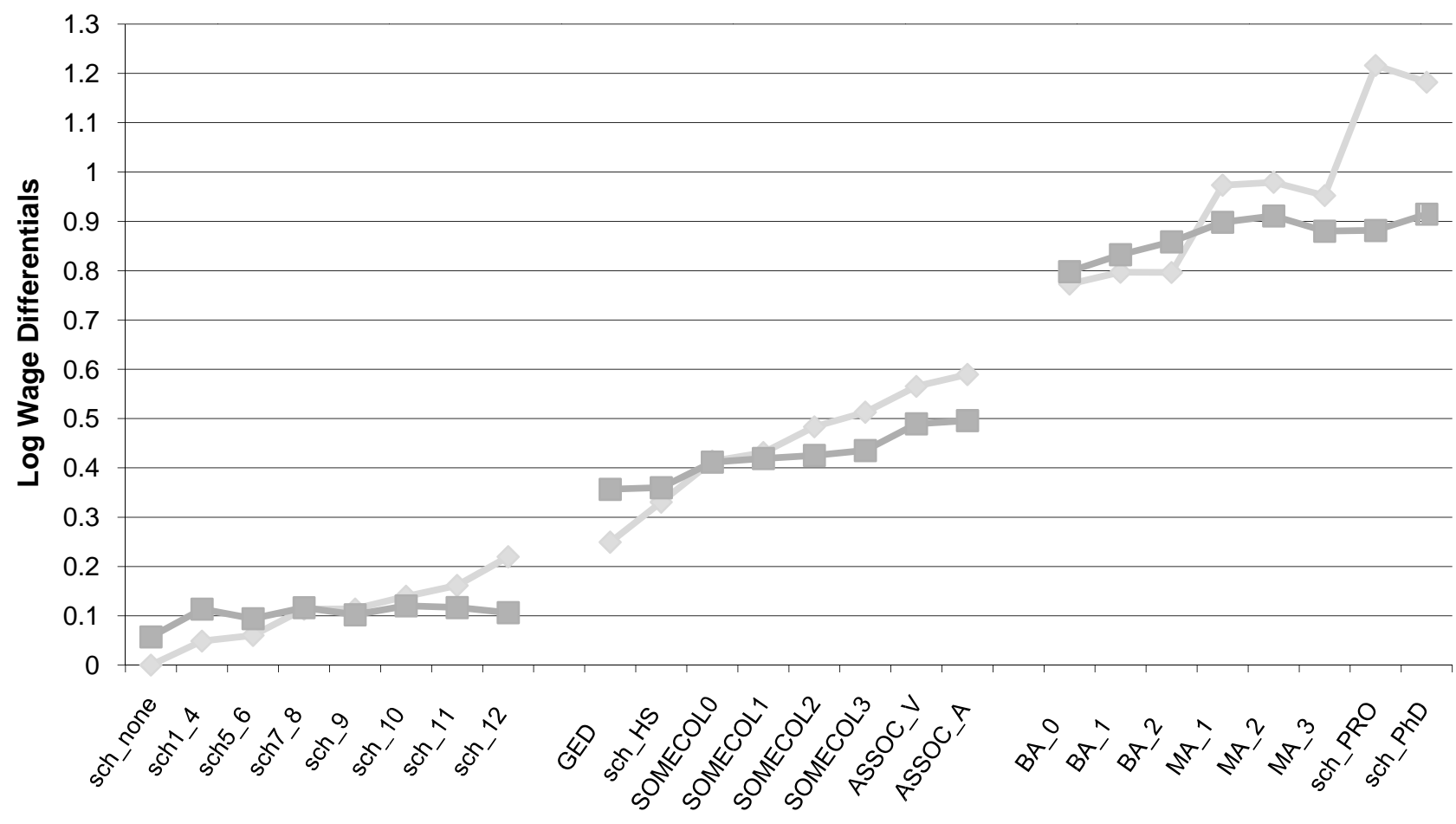

Educational Attainment

Not Imputed $\quad-$-Imputed

Source: Bollinger and Hirsch (2006). 
Fig. 3: Private Sector Union Wage Gaps With and Without Match Bias Correction

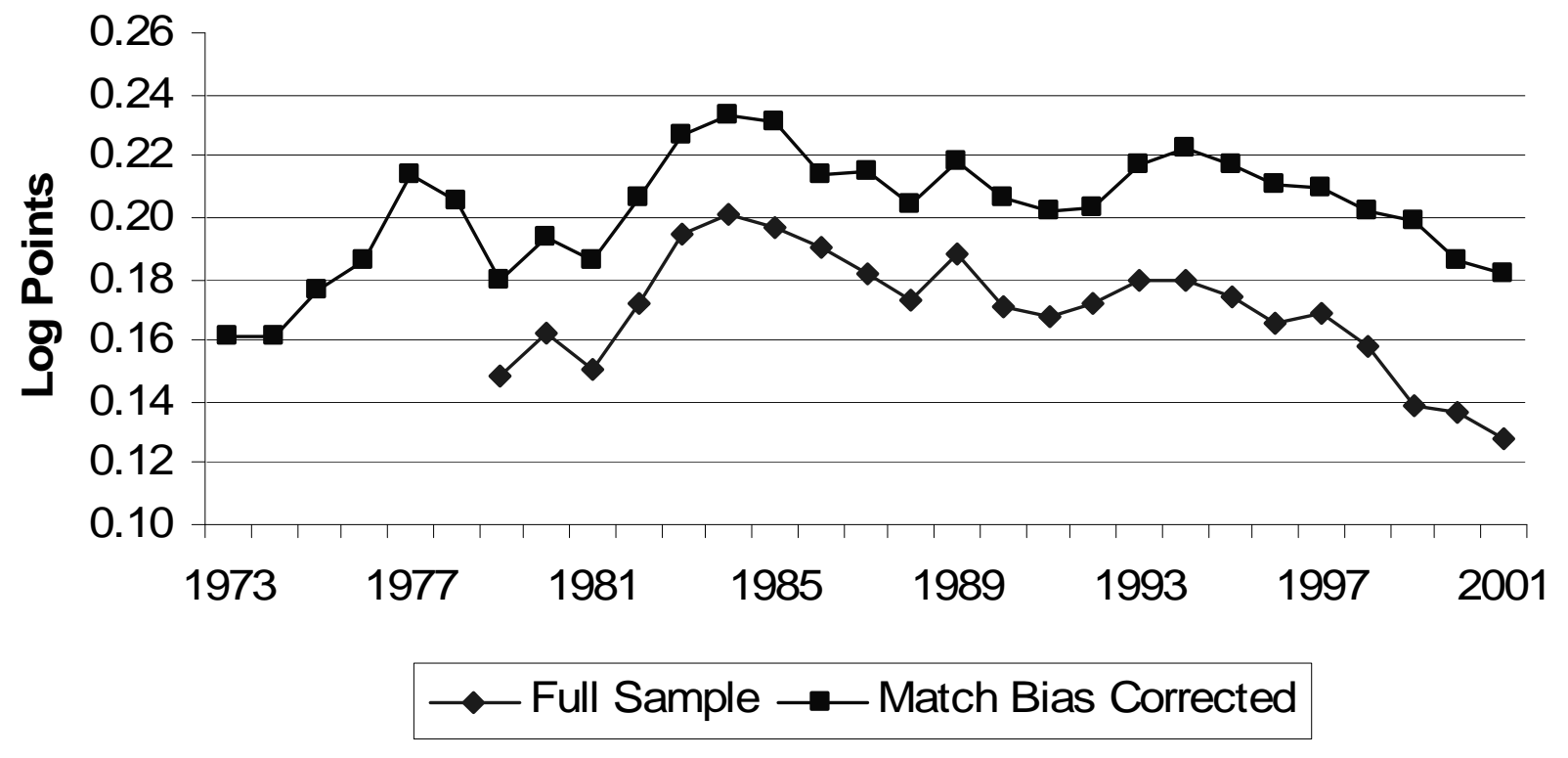

Source: Hirsch and Schumacher (2004).

Fig. 4: Union Wage Gaps by Education

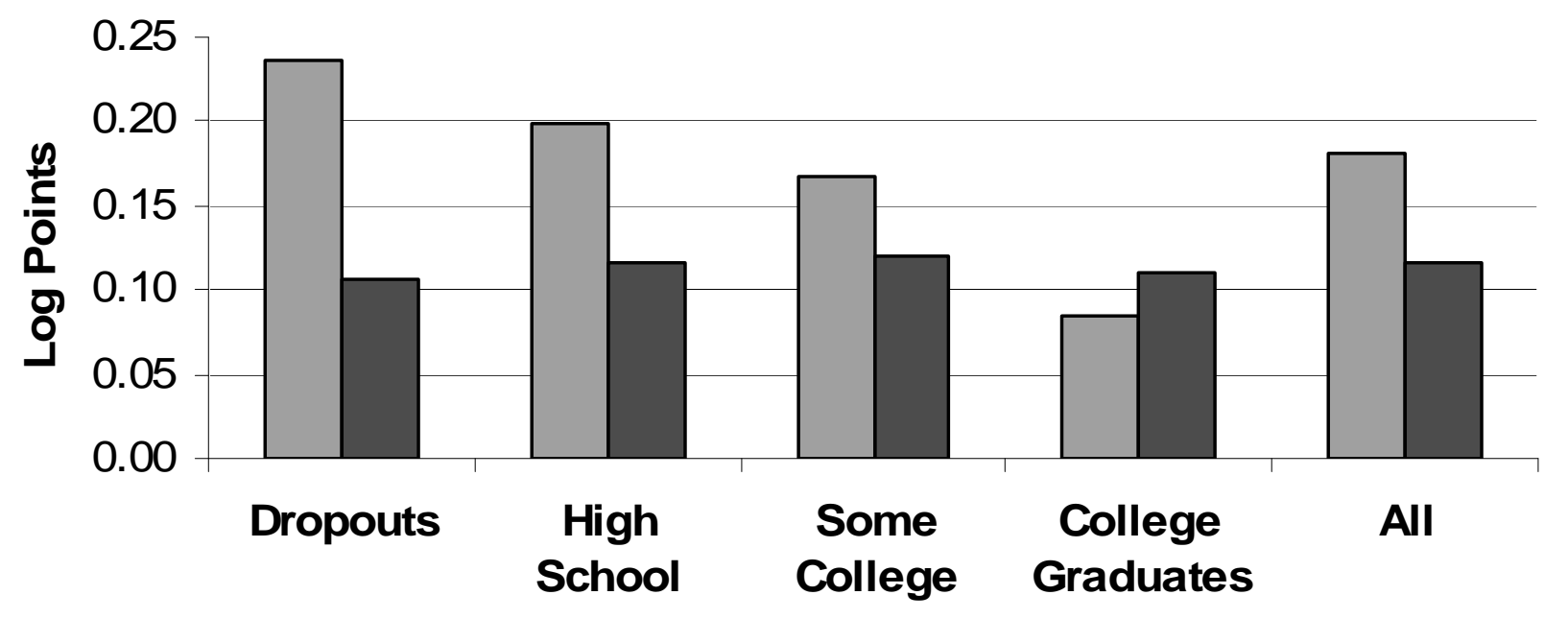

$\square$ Wage Level Eqs. $\square$ Wage Change Eqs.

Source: Hirsch and Schumacher (1998). 
Fig. 5: Union Density of Trucking Industry and Drivers, 1976-2006

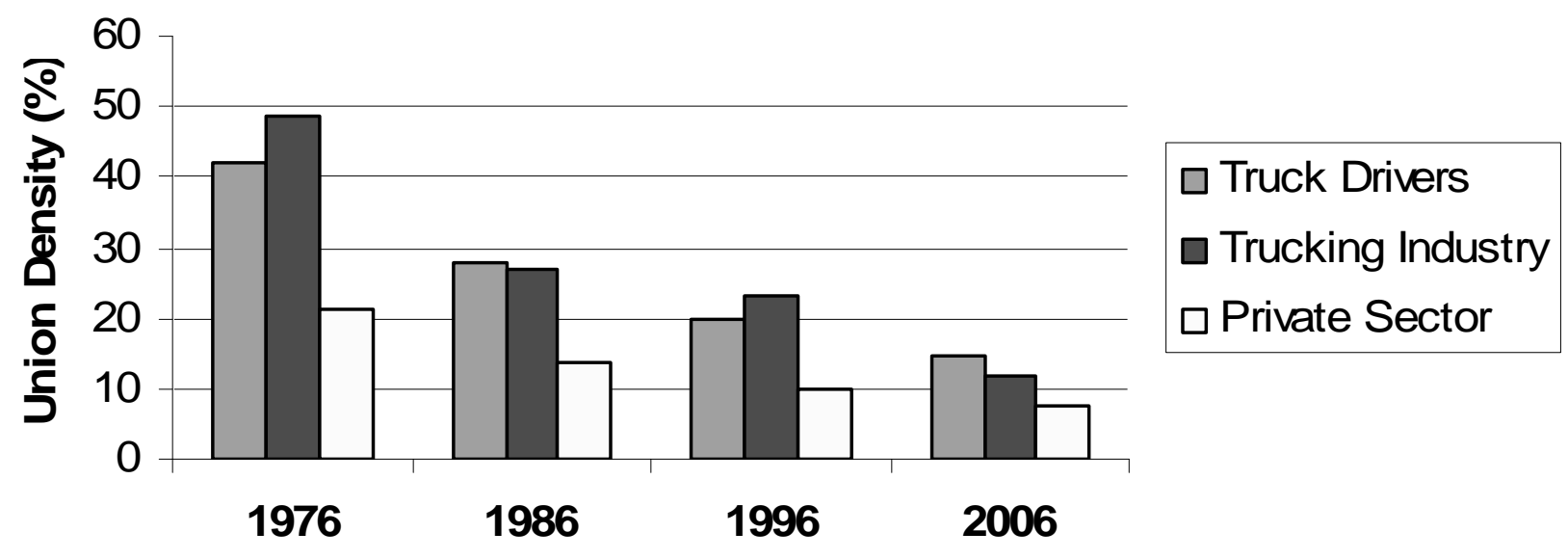

Note: Trucking Deregulation in 1980

Source: Hirsch and Macpherson (2003), updated database www.unionstats.com.

Fig. 6: Union and Nonunion Employment in Motor

Vehicle and Equipment Manufacturing, 1973-2006

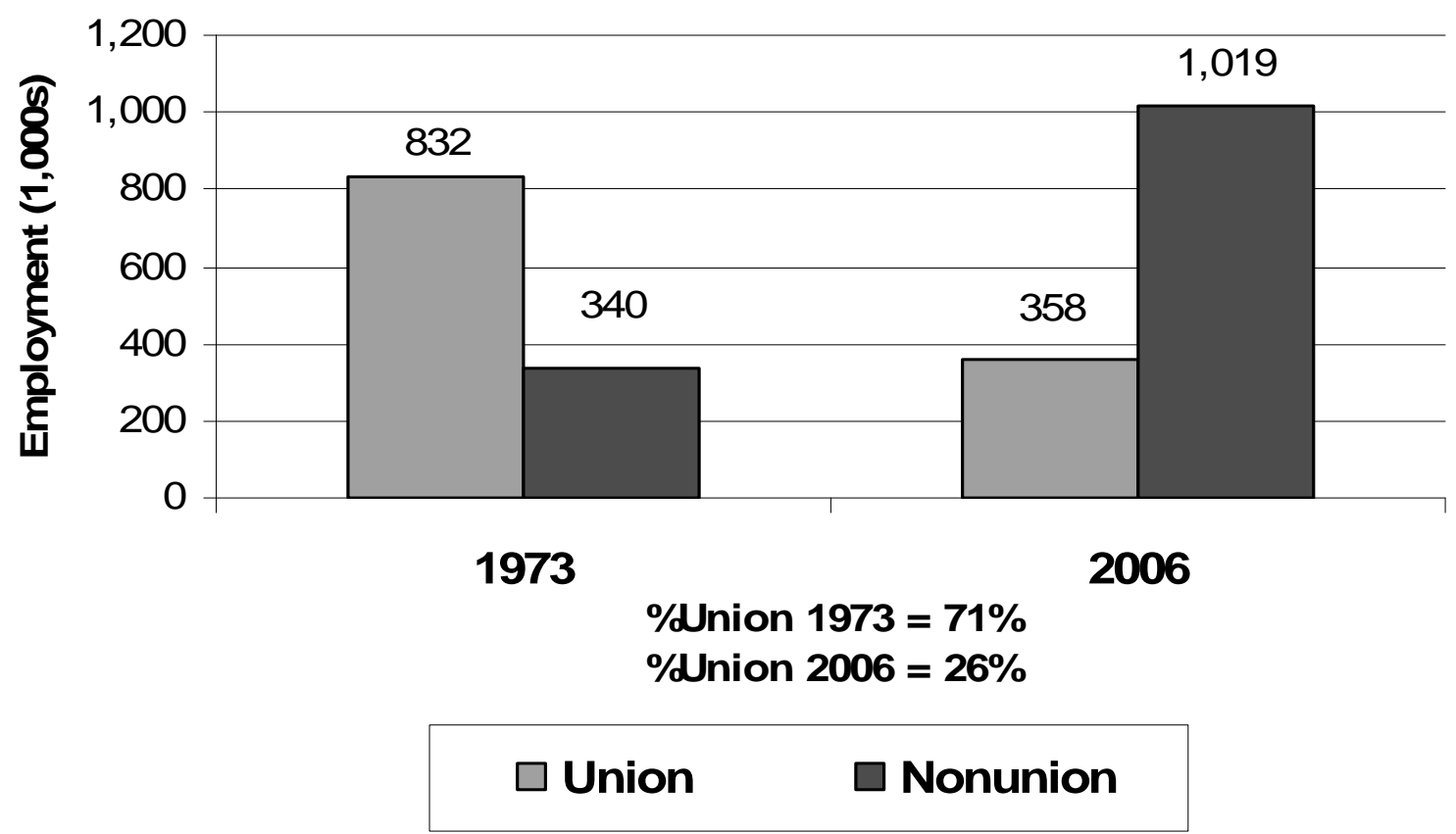

Source: Hirsch (2008). 
Fig. 7: Wage Premiums for Air Transportation Workers

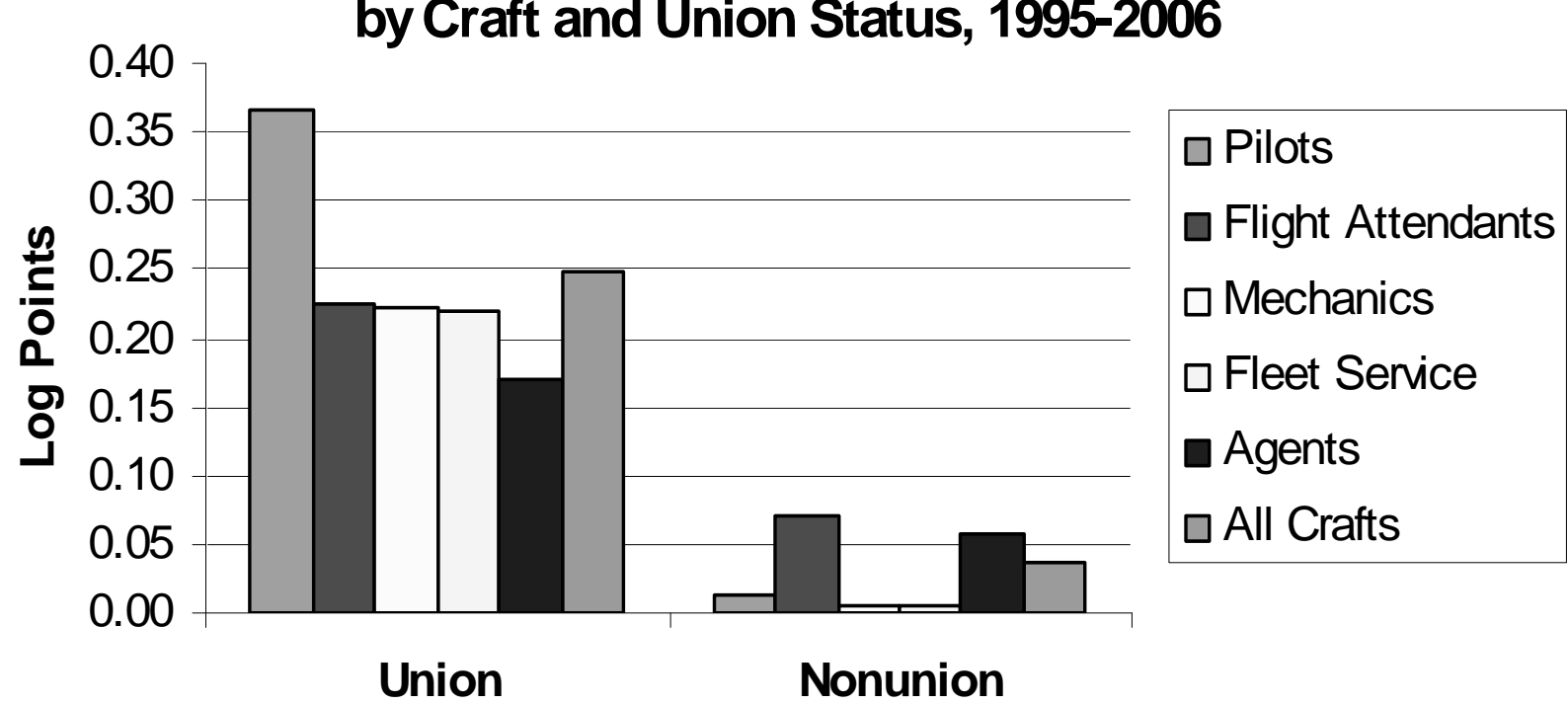

Source: Hirsch (2007).

Fig. 8: Real Wages of Nurses and

\section{Truck Drivers, 1976-2006}

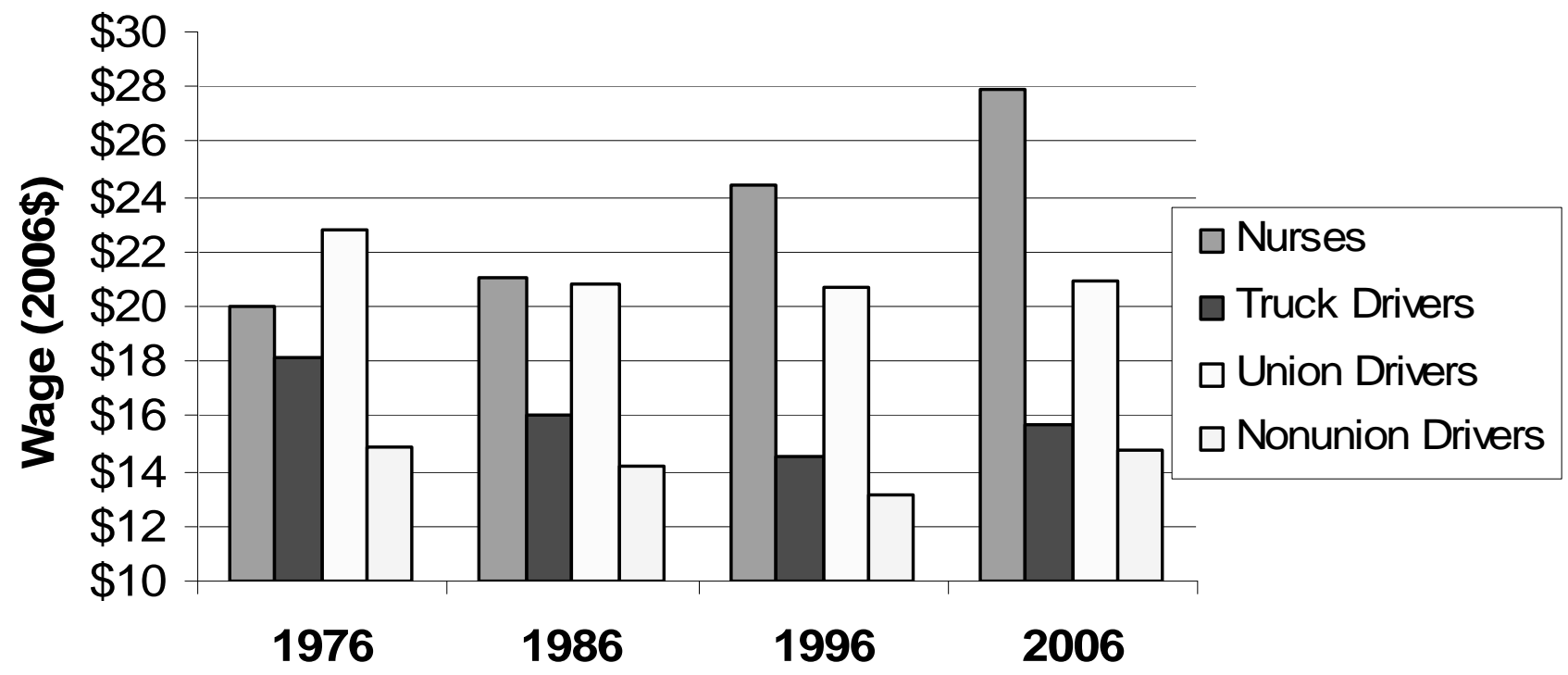

Note: Trucking Deregulation in 1980

Source: Calculations by the author from the 1975-77 May CPS

Earnings Files and the 1986, 1996, and 2006 CPS-ORG. 
Fig. 9: Intercity Wage Dispersion: Nominal, Full Price Adjusted, and Partial Price Adjusted

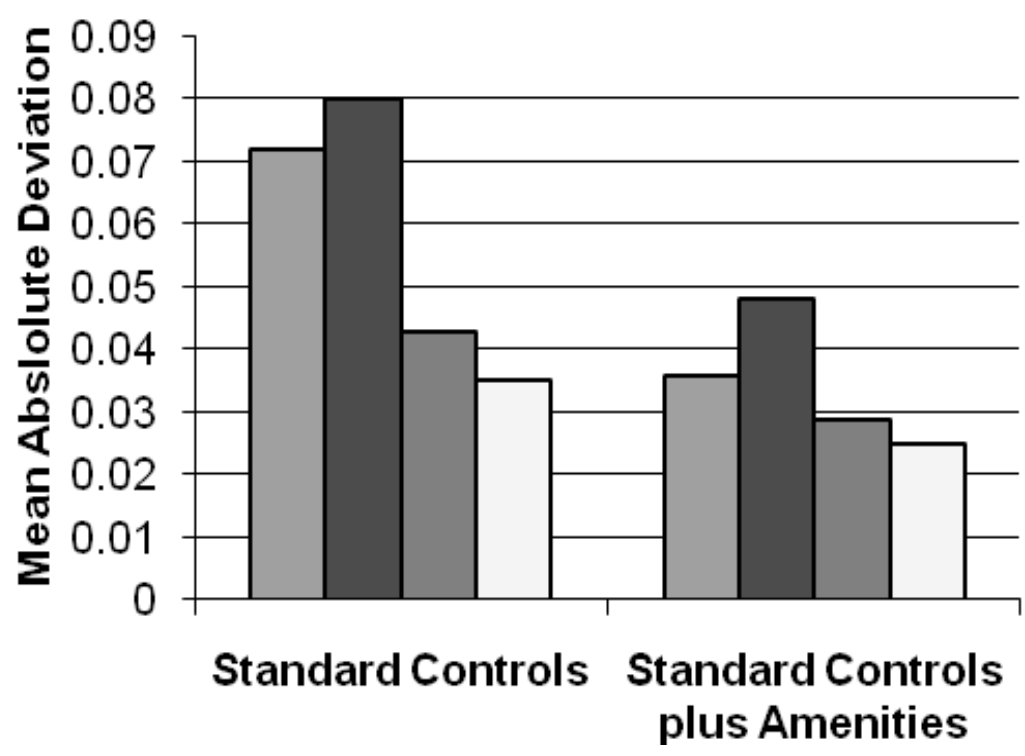

口Nominal

口Full price adj.

$\square$ Partial linear adj.

口Partial quadratic adj.

Source: DuMond, Hirsch, and Macpherson (1999).

Fig. 10: South/Non-South Wage Gaps:

Nominal, Full Price Adjusted, and Partial Price

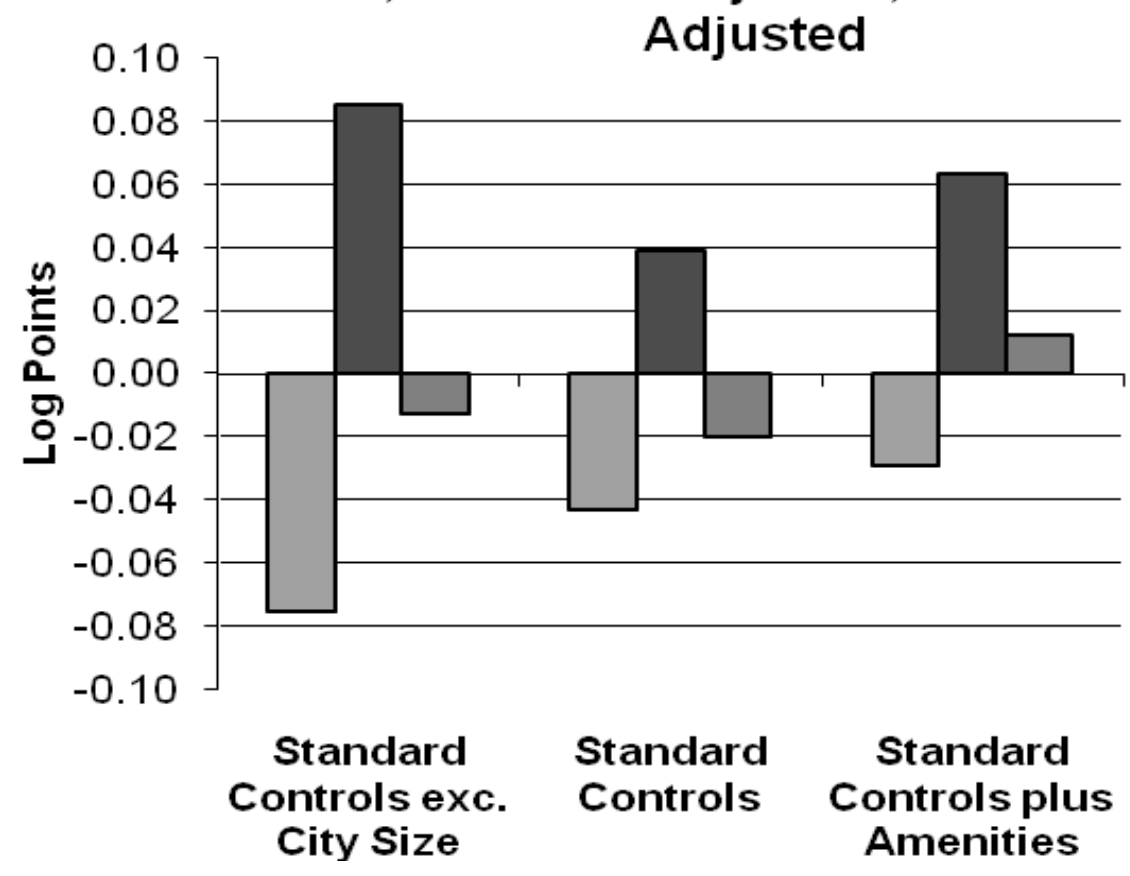

$\square$ Nominal

口full price adj.

$\square$ Partial linear adj.

Source: DuMond, Hirsch, and Macpherson (1999). 